\title{
STRAIN DIFFERENCES IN THE ENDOCRINE BASIS OF MATERNAL NEST-BUILDING IN THE RABBIT
}

\author{
M. X. ZARROW, V. H. DENENBERG AND \\ W. D. KALBERER \\ Departments of Biological Sciences and Psychology, \\ Purdue University, Lafayette, Indiana, U.S.A.
}

(Received 6th April 1965)

\begin{abstract}
Summary. The Dutch-belted and grey chinchilla strains of rabbits, Oryctolagus cuniculus, were compared for incidence of maternal nestbuilding after normal pregnancy, pseudo-pregnancy induced by human chorionic gonadotrophin ( $\mathrm{HCG}$ ), castration during pregnancy, oestradiol treatment during pregnancy and treatment of the castrated doe with oestradiol and progesterone. In both strains all does built nests at the end of normal pregnancy, but only $85 \%$ of the Dutch-belted does and $31 \%$ of the grey chinchilla does at the end of pseudo-pregnancy. All other treatments induced maternal nest-building in both strains; but the grey chinchilla rabbits required longer treatment for the induction of nestbuilding after castration and more oestradiol for the induction of nestbuilding during pregnancy. The critical period for the induction of maternal nest-building after castration in the pregnant rabbit is before Day 20 of gestation in the Dutch-belted and about Day 25 for the grey chinchilla strain.
\end{abstract}

\section{INTRODUCTION}

Strain differences have been reported for a number of characteristics of maternal behaviour in the rabbit, Oryctolagus cuniculus (Sawin \& Crary, 1953). Persistence of these strain differences has been established by Ross, Sawin, Denenberg \& Zarrow (1961), who analysed material collected over $6 \frac{1}{2}$ years on four strains: differences were found both in the percentage of rabbits building maternal nests and in the time at which nests were built. Indeed, it was possible to distinguish between strains in which the maternal nest is built before parturition from those which build at the time of parturition.

Since maternal nest-building is under hormonal control (Zarrow, Farooq, Denenberg, Sawin \& Ross, 1963), it was decided to examine the influence of hormonal disturbances on nest-building in two strains of rabbits. Previous work had shown that certain treatments which change the ratio of oestrogen to progesterone induced nest-building in ovariectomized rabbits (Zarrow et al., 1963). Other studies have shown that hair loosening, a component of maternal nest-building, is also under hormonal control (Farooq, Denenberg, Ross, 
Sawin \& Zarrow, 1963). The above studies were carried out on the Dutchbelted strain. In order to determine whether genetically different rabbits respond in the same way, the grey chinchilla was selected as a quite distinct strain. Grey chinchilla adults are about twice as heavy as Dutch-belted rabbits.

\section{MATERIALS AND METHODS}

The Dutch-belted rabbits came from the Purdue University colony, while the grey chinchillas were purchased from commercial breeders. The rabbits were housed in individual cages about $36 \times 90 \times 60 \mathrm{~cm}$ high and containing a nesting box $28 \times 56 \times 28 \mathrm{~cm}$ high. The animals received food and water ad libitum; hay was also constantly available for food or nest-building. All animals used in these experiments were young adults from 4 to 8 months of age. The Dutch-belted rabbits weighed between 2 and $3 \mathrm{~kg}$ and the grey chinchillas weighed between 3.5 and $5 \mathrm{~kg}$.

Maternal nest-building was studied: (1) during and after pregnancy, (2) during and after pseudo-pregnancy induced by human chorionic gonadotrophin (HCG) in the form of APL, Ayerst Laboratories, (3) after castration during pregnancy, (4) after interruption of pregnancy by oestrogen and (5) after treatment with oestradiol and progesterone to induce nest-building in ovariectomized rabbits.

The steroid hormones were dissolved in peanut oil and injected subcutaneously in a total volume of $0.1 \mathrm{ml}$. HGG was dissolved in saline and injected intravenously. Ovariectomy was carried out through a single midventral incision; the rabbits were anaesthetized with Nembutal intravenously (25 $\mathrm{mg} / \mathrm{kg}$ body weight) supplemented with ether when necessary. All animals were observed twice daily for signs of nest-building, abortion, etc.

\section{RESULTS AND DISCUSSION}

The results are summarized in Tables 1 and 3 .

(i) All rabbits of both strains built maternal nests during or after a normal pregnancy. After pseudo-pregnancy induced by the injection of 400 i.u. HCG intravenously on two successive days, only $31 \%$ of the grey chinchillas built maternal nests as compared with $85 \%$ of the Dutch-belted females.

(ii) In a second group of experiments the effect of ovariectomy during pregnancy was examined. Zarrow, Farooq \& Denenberg (1962) had already shown that maternal nest-building is induced in the Dutch-belted rabbit by removal of the ovaries during pregnancy; the necessary length of pregnancy was 14 to 17 days. None of the rabbits built maternal nests if ovariectomized before the 14th day of gestation. Thereafter the proportion which built nests increased progressively until all that were ovariectomized on Day 17 of the gestation did so. In our current experiment all the Dutch-belted rabbits built nests after ovariectomy on Day 20 of gestation. By contrast, none of the grey chinchilla rabbits ovariectomized on Day 15 , and only one out of eight ovariectomized on Day 20, built maternal nests. However, twelve out of fifteen grey chinchillas built nests when ovariectomized on Day 25 of pregnancy. Hence the 
required duration of pregnancy before nest-building can be induced by ovariectomy is much longer in grey chinchillas than in Dutch-belted rabbits. Maternal nest-building after ovariectomy in the pregnant rabbit always occurred within 2 to 4 days of removal of the ovaries, and earlier than could be expected from a normal pregnancy in either strain.

(iii) Zarrow et al. (1963) had already found that injection of $10 \mu$ g oestradiol benzoate on Days 20,21 and 22 of pregnancy always caused maternal nestbuilding in Dutch-belted rabbits. This was confirmed by our present experiments, in which eight out of eight Dutch-belted rabbits built maternal nests after injection. The same treatment failed to induce nest-building in any of six grey chinchilla rabbits. Indeed, treatment of eight additional grey chinchillas

TABLE 1

MATERNAL NEST-BUILDING IN DUTCH-BELTED (DB) AND GREY CHINCHILLA

(GC) RABBITS

\begin{tabular}{|c|c|c|c|c|}
\hline \multirow{2}{*}{ Treatment } & \multirow{2}{*}{ Strain } & \multirow{2}{*}{$\begin{array}{l}\text { No. of } \\
\text { rabbits }\end{array}$} & \multicolumn{2}{|c|}{$\begin{array}{c}\text { Rabbits that } \\
\text { built nests }\end{array}$} \\
\hline & & & No. & $\%$ \\
\hline Normal pregnancy & $\begin{array}{l}\text { DB } \\
\text { GC }\end{array}$ & $\begin{array}{l}15 \\
19\end{array}$ & $\begin{array}{l}15 \\
19\end{array}$ & $\begin{array}{l}100 \\
100\end{array}$ \\
\hline HCG-400 i.u. & $\begin{array}{l}\text { DB } \\
\text { GC }\end{array}$ & $\begin{array}{l}13 \\
13\end{array}$ & $\begin{array}{r}11 \\
4\end{array}$ & $\begin{array}{l}85 \\
31\end{array}$ \\
\hline $\begin{array}{l}\text { Castration during pregnancy } \\
\text { on Day } 20 \\
\text { on Day } 15 \\
\text { on Day } 20 \\
\text { on Day } 25\end{array}$ & $\begin{array}{l}\text { DB } \\
\text { GC } \\
\text { GC } \\
\text { GC }\end{array}$ & $\begin{array}{r}8 \\
7 \\
8 \\
15\end{array}$ & $\begin{array}{r}8 \\
0 \\
1 \\
12\end{array}$ & $\begin{array}{r}100 \\
0 \\
12 \\
80\end{array}$ \\
\hline $\begin{array}{l}\text { Injection of oestradiol benzoate on } \\
20 \mathrm{th} \text { to } 22 \mathrm{nd} \text { days of pregnancy } \\
10 \mu \mathrm{g} \\
10 \mu \mathrm{g} \\
20 \mu \mathrm{g} \\
40 \mu \mathrm{g} \\
40 \mu \mathrm{g}\end{array}$ & $\begin{array}{l}\text { DB } \\
\text { GC } \\
\text { GC } \\
\text { GC } \\
\text { GC }\end{array}$ & $\begin{array}{r}8 \\
6 \\
8 \\
3 \\
10\end{array}$ & $\begin{array}{r}8 \\
0 \\
0 \\
1 \\
10\end{array}$ & $\begin{array}{r}100 \\
0 \\
0 \\
33 \\
100\end{array}$ \\
\hline
\end{tabular}

* Injected twice daily on the three successive days with $20 \mu \mathrm{g}$ at each injection.

with $20 \mu \mathrm{g}$ of oestradiol benzoate still failed to induce nest-building. When the dosage was doubled again to $40 \mu \mathrm{g}$, one out of three built a maternal nest. The best results were obtained when $20 \mu \mathrm{g}$ was given twice daily on three successive days: all ten rabbits so treated built nests on Days 27 or 28 and resorbed the foetuses.

Here again we see a difference in the amount of oestrogen needed to induce maternal nest-building during pregnancy. The grey chinchillas required at least four times that needed by the Dutch-belted strain. The grey chinchilla is the larger strain, but none was more than twice the body weight of the Dutch-belted rabbits. Hence the requirement of the grey chinchilla rabbit is still at least twice that of the Dutch-belted, even if the dose of hormone is corrected for differences in body weight. Moreover, the treatment with $40 \mu \mathrm{g}$ oestradiol benzoate was made more effective by giving it to the grey chinchillas in two daily injections $8 \mathrm{hr}$ apart. 
(iv) Our previous results had indicated that a combination of oestrogen and progesterone induces maternal nest-building in ovariectomized rabbits (Zarrow, et al. 1963). Accordingly, rabbits were ovariectomized and, after at least 2 weeks, the rabbits were treated with $5 \mu \mathrm{g}$ of oestradiol and $2 \mathrm{mg}$ of progesterone daily for 12 to 30 days. Oestrogen treatment was started on the first day and followed by a combination of oestrogen and progesterone on the second and subsequent days (Table 2). At a designated time the progesterone

TABLE 2

SGHEMES OF TREATMENT WITH OESTRADIOL AND PROGESTERONE

\begin{tabular}{c|c|c}
\hline Oestradiol, $5 \mu g$ & Progesterone, 2 $m g$ & $\begin{array}{c}\text { Duration of treatment } \\
\text { (days) with both } \\
\text { hormones simultaneously }\end{array}$ \\
\hline Days 1 to 16 & Days 2 to 12 & 11 \\
Days 1 to 19 & Days 2 to 15 & 14 \\
Days 1 to 24 & Days 2 to 20 & 19 \\
Days 1 to 29 & Days 2 to 25 & 24 \\
Days 1 to 34 & Days 2 to 30 & 29 \\
\hline
\end{tabular}

TABLE 3

MATERNAL NEST-BUILDING IN OVARIEGTOMIZED DUTGH-BELTED (DB) AND GREY CHINCHILLA (GC) RABBITS TREATED WITH OESTRADIOL AND PROGESTERONE

\begin{tabular}{c|c|c|c|c|c|c}
\hline \multirow{3}{*}{ Strain } & \multicolumn{2}{|c|}{ Treatment } & $\begin{array}{c}\text { Duration of treatment } \\
\text { (days) with } \\
\text { both hormones }\end{array}$ & $\begin{array}{c}\text { No. of } \\
\text { rabbits }\end{array}$ & \multicolumn{2}{c}{$\begin{array}{c}\text { Rabbits that } \\
\text { built nests }\end{array}$} \\
\cline { 2 - 3 } & $\mu g O$ & $m g P$ & & No. & $\%$ \\
\hline DB & 5 & 2 & 11 & 5 & 0 & 0 \\
& 5 & 2 & 14 & 8 & 8 & 100 \\
GC & 5 & 2 & 14 & 8 & 0 & 0 \\
& 5 & 2 & 19 & 8 & 4 & 50 \\
& 5 & 2 & 24 & 12 & 8 & 67 \\
& 5 & 2 & 29 & 5 & 5 & 100 \\
& 10 & 4 & 29 & 2 & 2 & 100 \\
\hline
\end{tabular}

was stopped and the oestrogen continued for another 3 to 5 days. If maternal nest-building occurred it usually took place 2 to 4 days after the end of the progesterone treatment. The findings are summarized in Table 3.

Again our observations on the Dutch-belted rabbits confirmed our previous findings with that strain: treatment with both oestradiol and progesterone for 11 days failed to induce nest-building in five ovariectomized rabbits, whereas treatment for 14 days induced nest-building in all eight. Treatment of ovariectomized grey chinchilla rabbits with both hormones for 14 days failed to induce nest-building in any of eight animals; but after treatment for 19 days $50 \%$ of the rabbits built maternal nests; treatment for 24 days gave $67 \%$ nestbuilding, and 29 days gave $100 \%$. 
These results confirm that maternal nest-building in the rabbit follows a change in the oestrogen-progesterone ratio. The differences in the hormonal requirements for maternal nest-building in the Dutch-belted and grey chinchilla rabbit are evidently quantitative. Grey chinchilla does require either longer treatment or more hormone.

\section{ACKNOWLEDGMENTS}

This work was aided in part by a grant, GM 06263, from N.I.H. The HCG was obtained through the courtesy of Dr J. B. Jewell, Ayerst Laboratories, New York, N.Y.

\section{REFERENCES}

Faroo,, A., Denenberg, V. H., Ross, S., SAwin, P. B. \& Zarrow, M. X. (1963) Maternal behavior in the rabbit: Endocrine factors involved in hair loosening. Amer. F. Physiol. 204, 271.

Ross, S., Sawin, P. B., Denenberg, V. H. \& Zarrow, M. X. (1961) Maternal behavior in the rabbit: Yearly and seasonal variation in nest building. Behavior, 18, 154.

SAwIN, P. B. \& CRARY, D. D. (1953) Genetic and physiological background of reproduction in the rabbit. II. Some racial differences in the pattern of maternal behavior. Behavior, 6, 128.

Zarrow, M. X., Farooo, A. \& Denenberg, V. H. (1962) Maternal behavior in the rabbit: Critical period for nest building following castration during pregnancy. Proc. Soc. exp. Biol. Med. 111, 537.

Zarrow, M. X., FarooQ, A., Denenberg, V. H., Sawin, P. B. \& Ross, S. (1963) Maternal behaviour in the rabbit: Endocrine control of maternal-nest building. 7. Reprod. Fertil. 6, 375. 